\title{
What's in a name: a comparison of Chinese and Japanese approaches to the translation of chemical elements
}

\author{
Hao Chang ${ }^{1}$ (1) \\ Received: 6 July 2018 / Accepted: 17 August 2018 / Published online: 24 September 2018 \\ ๑) Springer Nature Switzerland AG 2018
}

\begin{abstract}
When we research the development of Chinese terms in chemistry, a historical study of the Japanese approach to chemical nomenclature needs also to be considered. The Chinese terms yuansu (element), yuanzi (atom), fenzi (molecular), dangliang (valence), youji (organic) and wuji (inorganic) were derived from Japanese, and were introduced after the Sino-Japanese War (1894-1895). However, the Chinese nomenclature had also a great impact on the development of Japanese terms in chemistry. So the influence of the Chinese terms is no doubt a point to be discussed when considering chemical terms in Japanese. The term huaxue (chemistry), for example, was coined in the middle of nineteenth century in China and was then introduced into Japan soon after. The Japanese term kagaku (chemistry) came to be widely used in public in the 1870s.
\end{abstract}

Keywords Chemical nomenclature $\cdot$ Chemical terms $\cdot$ John Fryer $\cdot$ Xu Shou $\cdot$ Udagawa Yoan

\section{Introduction}

After the defeat of the First Sino-Japanese War of 1894, many Chinese students went to Japan to receive Western education for many reasons, such as cultural similarities, geographical proximity and cost effectiveness. A great number of Japanese books translated from Western sources were translated into Chinese by them when they had finished education. Chinese people began to adopt unmodified Japanese kanji nouns, such as science (“科學”), culture (“文化”), philosophy (“哲學”), politics (“政治”), economics (“經濟”), civilization (“文明”), and society (“社會”) [1]. Many daily and technological Chinese terms used today originated in Japan. However, some native Chinese terms were mistaken as adopted Japanese terms and vice versa as demonstrated by reader's letter in newspapers.

This letter, entitled "No More Calling Oxygen by Its Incorrect Japanese Name", was posted to the 'China Times'. In 1949, a fiasco broke out regarding a fertilizer company's land development. At the time of its establishment, the said company, “高雄硫酸鋞公司” (The Kaohsiung Liusuanya Company), was named using an obsolete term [2]. This

Hao Chang

changhao@isu.edu.tw

1 Center for General Education, I-Shou University, Kaohsiung City, Taiwan, Republic of China author discussed his idea about the use of outdated Japanese chemical terms in Chinese language. His views were mostly highly useful. However, some of his points were incorrect.

The Chinese words for ammonium, 䥄 (ya) and 銨 (an), are both native. The word 鋹 $(y a)$ is known to be created as early as 1898 [3]. Ammonium was taken as a metal during the mid-nineteenth century [4]. As a result, it was written with a radical for metal (金, jin) by the creator of this word. In the very early days of China's exposure to modern science, many terms were phonetic transcripts. Ammonium also had a phonetic name [5]. The Science Noun Review Committee, 1925-1927, adopted the word 銈 (ya). Later in 1933, the word 銨 (an) replaced 銬 ( $y a$ ) as ammonium's new official name [6]. However, the obsolete word was here to stay. For instance, a Nanjing factory established in 1934 used the obsolete word in its name [7]. Japan used the phonetic method almost exclusively. During the Meiji era (1868-1912), Japanese chemical terms were mainly written in phonetic kanjis [8]. These kanji names were later replaced by new names written in katakana-a Japanese syllabary script [9]. The rarely used term “硫安” (liuan) for ammonium sulfate was only used in Japanese language [10]. Since the very beginning, silicon was known as a non-metal. None of its Chinese names has the radical for metals. Many glassrelated Chinese names were created and abandoned without having the radical for metals. 
In addition to the mistaken words mentioned before, it is believed that the origins of many other Chinese chemical words were also misunderstood. In this article, we shall investigate the creation and evolution of the names of many Chinese and Japanese chemical elements, inorganic compounds and organic compounds to discover hidden issues in China and Japan's adoption of chemical science. We shall clarify the origins of the words to establish a broader picture regarding the two countries' interactions and mutual influences in science.

\section{The names of chemical elements in Chinese}

Chemistry is a science that studies the composition and changes of matters. Ever since classic Greek times, the theory of elements has been quite popular in the Western World. At first, earth, wind, fire and water were taken as four basic elements. Not until as late as the eighteenth century did French scientist Antoine Laurent Lavoisier (1743-1794) establish the modern definition of elements that marked the beginning of today's chemistry. Starting from the nineteenth century, China has been introduced to chemical science. Knowing the elements was the first step to chemical studies. Understanding the elements could open the door to more advanced chemistry. As a result, scholars began to create Chinese names for the elements [11].

Benjamin Hobson (1816-1873), a British medical doctor and priest, was the first to introduce elements to China even before the government's modernization movement known as the Self-Strengthening Movement (1861-1895). He wanted to open Chinese minds and souls using science as a way to spread the Christian Gospel [12]. In the Tienwen Luelun ( 天文略論, A Brief Introduction to Astronomy) of 1849, he named oxygen and nitrogen to explain the compositions of the air, “One of the elements is yangqi (“養氣”) which nourishes (“養”, yang) the life. The other one is danqi ( 淡氣) which dilutes (淡, dan) the air's nourishing component". This was the first instance when modern elements were taught in China. Two years later, he introduced the third element hydrogen to China in his Bowu Xinbian (博 物新編, New Treatise on Natural Philosophy and Natural History), “Qingqi (“輕氣”) or shuimuqi (“水母氣”, gas that creates water) is obtained from water. ... which is the lightest (“輕”, qing) of all.” [13]. This book on natural science was listed as one of the five great medical science books which included Quanti Xinlun (全體新論, New Theories on the Gross Anatomy, 1851), Xiyi Luelun (西醫略論, A Brief Treatise on Western Medicine, 1857), Fuying Xinshuo (婦 貝新說, New Ideas on Mother and Child, 1857) and Neike Xinshou (內科新說, New Ideas on Internal Medicine, 1858) [14]. His Bowu Xinbian was highly praised by John Fryer (1839-1928) as the dawn's first light that opened Chinese scholars' minds to science after the first attempt by the
Jesuits at the turn of Ming and Qing Dynasties [12]. This book mentioned the discovery of 56 elements. However, he did not mention these elements other than oxygen, hydrogen and nitrogen. These three names are still used in the Chinese language [15].

After the Qing government's beginning of its modernization efforts, many chemical books were translated into Chinese and opened a new age of Chinese chemistry. First, William A. P. Martin (1827-1916) of the American Presbyterian Church introduced more chemical elements in his Gewu Rumen (格物入門, Introduction to Natural Philosophy) of 1868. Martin used two methods to name elements in Chinese. Some element names were derived from their classical Chinese names, such as menshi (“蒙石”, manganese), heiqian (“黑鉛”, black lead, lead), baiqian (“白 鉛”, white lead, zinc), xinshi (“信石”, arsenic), bojing (“ 玻精”, silicon), fanjing (“攀精”, aluminium), pengjing (“ 硽精”, boron), and tanjing (“炭精”, carbon). Many others were named based on their properties, such as huijing (灰 精, essence of potash, potassium), hailan (海藍, sea blue, iodine), baijin (白金, white gold, platinum), guangyao (光 藥, light substance, phosphorus), yanqui (鹽氣, salt gas, chlorine), jianjing (堿精, essence of base, sodium), and shijing (石精, essence of limestone, calcium) [16]. The use of the word jing (精, essence) in elements' names was influenced by Chinese alchemy. Martin believed the Chinese idea of a material's essence was more or less the same as the element of modern science [17].

Two years later, many churches, Beijing Tonwenguan and Shanghai's Jiangnan Arsenal, published a number of chemical books and created many more Chinese names for the elements. Today's Chinese element names are usually in the form of phono-semantic compounds (形 聲, xíngsheng). Some of them were created based on the elements' original meanings while some others consist of a physical-state semantic radical plus a phono modifier selected according to the said element's Latin-based name's first, second or third syllable. Nearly all metal elements consist of a metal radical (金, jin) with a phono modifier. For example, 銻 ( $t i$, antimony), 鋇 (bei, beryllium), 鉍 (bi, bismuth), and 鎂 (mei, magnesium) belong to this category. Elements such as 矽 ( $x i$, silicon), 碲 ( $t i$, tellurium) and 碘 (dian, iodine) were created with the stone radical (石, shi) while 溴 (xiu, bromine) and 永 (gong, mercury) were created with the water radical (水 or $\forall, ~ s h u i)$ and 燐 (lin, phosphorus) has a fire radical (火, huo). Many of these names were created by John Fryer and Xu Shou (徐壽, 1818-1884) in the book Huaxue Jianyuan (化學鑒原, Elementary Chemistry) translated by them in 1871. Sixty-four chemical elements were introduced by this book which included 10 traditional names, 金 (jin, gold), 銀 (yin, silver), 銅 (tong, copper), 鐵 (tie, iron), 錫 (xi, tin), 鉛 (qian, lead), 碳 (tan, carbon), 硫 (liu, sulfur), 
永 (gong, mercury), and 燐 (lin, phosphorus). Several recently-created names considered to be good were also adopted, including 養 (yang, oxygen), 輕 (qing, hydrogen), and 淡 (dan, nitrogen) created by Benjamin Hobson. The name 白金 (baijin, platinum), created by William A. P. Martin, was consolidated into a phono-semantic word 鉑 (bo, platinum). The phono-semantic approach of word formation was adopted to standardize element names into single-word units so they could be written like symbols to simplify the formation of inorganic compound names, "Now we name the elements using single words. Chemical compounds' names can be formed using the names of their component elements". Among the 39 created element names, except for 綠 (lü, chlorine) and 溴 (xiu, bromine), 37 of them were phonetic transcripts. This approach was unusual to people of that particular era. Most Chinese people knew practically nothing about Latin alphabets. Very few of them could spell. These phonetic words "are probably good enough for gossiping. They provide no further clues for detailed discussions." [18]. Furthermore, Chinese people tend to prefer meaningful names. Chemical names that do not carry literal meanings are simply considered not usable. However, to John Fryer and Xu Shou, "a word could hardly carry an element's full properties while a faithful syllable-by-syllable transcription might be tediously lengthy". Using a syllable plus a meaning-based radical became a good compromise to them for their naming works [19].

Some of these newly coined words actually appeared in Huaxue Chujie (化學初階, Basic Chemistry) translated by John Glasgow Kerr (1824-90), a medical doctor and an American Presbyterian Church priest, and HE Liaoran ( 何瞭然) in 1870. Kerr already knew the names of these elements because Fryer sent them to Kerr for his opinion before publishing [20]. This was disclosed in Kerr's English preface to the Huaxue Chujie [21]. He did not mention the methodology of these words' creation because they were created by others [22].

The take-one-syllable approach by Fryer and Xu was certainly more convenient in comparison with another set of element names used by Jinshi Shibie (金石識別, Discrimination of Mineralogy). Some of Huaxue Jianyuan's element names were created in response to this book's names. For instance, in Jinshi Shibie, silicon (“夕里西 恩”, xilixien), strontium (“息脫浪西恩”, xitoulangxien), terbium (“式而比恩”, teerbien), uranium (“由日尼恩”, yourinien), and vanadium (“凡宗地恩”, fannaidien) were given lengthy names having three to five one-syllable words. These names were overly lengthy for most Chinese speakers to memorize. In Ниахие Jianyuan, the earlier names' first words were isolated and added type-related radicals to form names that were easier to read and write, including silicon (“矽”, $x i$ ), strontium (“鎴”, $x i$ ), terbium
(“鐡”, te), uranium (“鈾”, you), and vanadium (“釩”, fan). Jinshi Shibie was translated from James Dwight Dana's (1813-1895) "Manual of Mineralogy" by Jiangnan Arsenal's Daniel Jerome MacGowan (1814-1893) who was an American priest [23].

The one phono-semantic compound name approach was not only accepted by John Glasgow Kerr but also accepted by Anatole Billequin (1837-1894), a French chemistry teacher of Beijing Tongwenguan. However, he disliked the phonic approach of word formation. In the book Huaxue Zhinan (化學指南, A Guide to Chemistry) translated by him and his student Lian Zhizhen (聯子振), he used a named-byits-meaning approach. Since there existed a great variety of Chinese dialects, this approach could have created a great number of dialect-based phonic transcripts. As a result, he chose to use the elements' chemical properties as his naming basis.

Many elements' names are not known in China. It is difficult to write down their European pronunciations using Chinese words. There are also too many Chinese dialects and accents for the phonic approach. We would like to create names based on the elements' properties. This approach is better than the named-after-its-look approach taken by earlier scholars. Therefore, many names used in Huaxue Zhinan were coined from their original meanings, for example: 石月 (selenium), "its color was similar to that of the moon (月) at the time of its discovery", 石地 (tellurium), "named because it was colored like the earth (地)", and 鍕 (barium), "a metal from a kind of heavy earth (埵)". Some words were created after the properties of an element's chemical compound, such as 錆 (cobalt), “this metal's salt is sky blue (青)” and 鋯 (chromium), and "the salt of this element can generate many colors (生色)" [24].

Knowing that naming chemical elements can be very difficult, Anatole Billequin still took the meaning-based approach. He used the element's original meaning, chemical properties and its own or its important compound's color to create a Chinese word for it. This approach was realizable because Billequin was familiar with many elements' history and their chemical properties.

Before Fryer and Xu's adoption of the phono-semantic approach, Wilhelm Lobscheid (羅存德, 1822-1890) of the Rhenish Missionary Society had already invented a very similar approach. He used the Chinese word “行” (xing, a traditional Taoism name for elements) to name elements. Then he divided the word “行” into a left part (₹) and a right part ( $\overline{\mathrm{J}})$ with a descriptive part sandwiched in the middle. Many traditional Chinese words were formed in that manner, such as 衍, 術, 街, 衝, and 衛 [25]. Lobscheid created some of his words based on an element's original meanings, such as 街 (tellurium), 行 (uranium), and德 (tungsten). Some others were named after the element's 
color, say, 锆 (vanadium), or its important compound's color, for instance, 街 (titanium) and 衝 (zirconium) [26]. The names created by Lobscheid were almost totally forgotten without leaving much influence.

After the First Sino-Japanese War of 1894, many Christian churches in China began to promote unified translation of scientific documents [27]. In 1898, the Educational Association (㿽智書會) and China Medical Missionary Association (博醫協會) published "the Revised List of Chemical Elements” (化學元素名詞修正表) hoping it would clean up the mess caused by unstandardized names created by the churches, Beijing Tongwenguan and Shanghai's Jiangnan Arsenal. The two committees determined to adopt the meaning-based approach to name gaseous and other vital elements. Some of Fryer and Xu's phonic names were forced to change under the new policy, including, 紫 ( $z i$, violet, iodine), 克 ( $k e$, fluorine氟), 硄 (guang, light, phosphorus), 䃉 (jing, crystal, silicon), 釷 ( $t u$, earth or alum, aluminium), 鍋 ( $g u$, bone, calcium), 鐄 (huang, yellow, chromium), 鐻 ( $l u$, brine, sodium), 鉦 (zheng, positive, zinc), and 銈 ( $m o$, dark-colored, manganese). On the other hand, some phonic names were also changed. Fryer sent them his complain letters [28]. In 1901, the two church institutes published Chemical Terms and Nomenclature (化學名詞與命名). The most significant changes were the adoption of the gas radical (气) for gaseous elements, such as 㝗, 輕, 氮, and 氯. Most of the other elements remain unchanged in comparison with the previous list [29].

In the early days of the twentieth century, many Japanese books were translated into Chinese. Many Chinese names for elements were affected. Some translators used the word “素” ( $s u$, essence) for elements, such as “新素” ( $x i n s u$, new element, neon) and “惰素” (dousu, inert element, argon) [30]. Many others were phonically transcribed from their Japanese katakana names, say, “洌媼” (lieyun, neon) and “克里卜 同” (kelibutong, krypton) [31]. A few of them were adopted Japanese kanji, such as, “酸素” (suansu, acid essence), “ 水素” (shuisu, water element, hydrogen), “窒素” (zhizu, unbreathable element, nitrogen), “鹽素” (lü, salt element, chlorine) and “蒼鉛” (cangqian, dark lead, bismuth) [32]. It is noteworthy that the officially compiled Ниахие Yuhui ( 化學語彙, A Chemical Vocabulary), issued in 1908 by the Ministry of Education, nearly adopted all of the names used by Huaxue Jianyuan [33].

After the establishment of the Republic in 1912, the new government's Ministry of Education issued a Draft of Inorganic Nomenclature (無機化學命名草案) [34]. During the time of political power struggle, many did not take the official list seriously. A medical nomenclature committee was established in 1915, and another chemical meeting was held in January 1917. Both of them used an unofficial list compiled by the National Medical and Pharmaceutical
Association of China, China Medical Missionary Association, and the Association of Science Education as their main source and ignored the government's list [35].

In the medical nomenclature review meetings, the naming of oxygen, hydrogen, nitrogen and chlorine became the most intensely debated issue. In the first chemical nomenclature review meeting, no one was willing to compromise. In the end, four pairs of equivalent names, 䓹/養, 輕/輕, 氮/淡, and 㮌/綠, were proposed [36]. Yu Fengbin (1884-1930), on behalf of the Chinese Medical Association, told the press after the meeting, "We can accept the use of many traditional words. However, the words '輕' (qing, light-weight), “淡” (dan, dilution), ‘養' (yang, nourishment), and “綠' (lü, green) can hardly be used to fully describe the nature of these four gaseous elements. We have to create four new

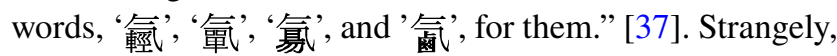
two newly coined words “晹” and “㬝” replaced previously named “䑆” and “氮” without any discussion [38]. Other than these debated words, many accepted old words were from Hиахие Jianyuan.

The Science Noun Review Committee's efforts went to a grinding halt in 1928 because of the change of government due to China's civil war. Shortly after the establishment of the National Institute for Compilation and Translation (國 立編譯館), a chemical discussion panel was held in Nanjing in June 1932 and invited all the country's chemical scholars and experts to attend. They were there to review and vote for the chemical terms proposed by the Institute which was compiled by Zheng Zhengwen (1891-1969), the In-House Reviewer of Natural Sciences. In the end, his proposal almost passed in full without much challenges. After the review, the Ministry of Education and the Institute co-established a commission to review chemical terms with Zheng being the Chief Commissioner. They published the Principles of Chemical Nomenclature (化學命名原則) in 1933.

As to the elements' names, the review committee used the Ministry of Education's 1915 list as its starting point. They compared the list's names against names created by earlier scholars, e.g., Fryer and $\mathrm{Xu}$, and kept the names shared by the two sources. Some of the names were modified from their traditional names. For instance, “碳” (tan, carbon) and “磷” (lin, phosphorus) were selected as the official names while “炭” (tan) and “磷” (lin) were recognized as common names. In the case of arsenic, the committee determined " 砷” (shen) is created to be phonetically similar to arsenic while “砒” (pi) is a traditional word. The term “白砒” (baipi, white arsenic) refers to arsenic(III) oxide or arsenic trioxide. To reduce confusion, they decided to adopt “砷” (shen). In the case of silicon, they determined to use "移" ( $x i$ ) because another candidate “硅” (gui) was directly adopted from its Japanese name “珪素” (keiso, silicon element). “Since the word did not have a semantic root in Chinese, we'd rather use a phonetic approximation". Regarding the long disputes 
over names for hydrogen, oxygen, nitrogen, and chlorine, the committee determined to use the 1915 Ministry of Education names. The newly created words “晹”, “㲷”, and “畧 " introduced by the medical committee (they did not invent a new word for hydrogen) were abolished because "these words' meanings and pronunciations were forcefully applied and criticized by many. We cannot adopt these words". They determined to use “氫” (qing, hydrogen), “氧” (yang, oxygen), “氮” (dan, nitrogen), and “氯” (lü, chlorine). These words are still used today. As to the inert gases, they determined to use “氢” (nai) because another name “文” (na) was too similar to “鈉” ( na, sodium). The word “氙” (shan) was chosen as the name for xenon because of its pronunciation. Another candidate "無” was not chosen because it was semantic. All other inert gases were phonically transcribed, it was a departure from the de facto rule [34].

Regarding the names of metal elements, “鈹” ( $b i$, beryllium), “鈧” (kang, scandium), “鈦” (tai, titanium), “銠” (lao, rhodium), “銫” (se, cesium), “鉭” (tan, tantalum), and “銪” (you, europium) were chosen because "they have fewer strokes" and easier to write. As to “鎵” (jia, gallium), “鍺” (zhe, germanium), “釔” (yi, yttrium), “鍶” ( $s i$, strontium), “鏑” ( $d i$, dysprosium), and “鋨” ( $e$, osmium), "we choose to use previously determined words after a case-by-case review". Regarding radium, they used “鐳” (lei, phonic word) because most metal elements were named phonically and the alternative choice "銧” (guang, light or radiation) was created after its meaning which was deviated from common practice. Two words, “鈮” ( $n i$ ) and “鈛” (guo) were created for niobium. The word “鈛” (guo) was opted out because it was too similar to the word “錢” (qian, money) that may cause unneeded confusion. They choose to create a new word “鈳” ( $k e$ ) because at that time, American and European scientists were still struggling for the right to name that element and the American name "columbium" was more widely used. Another word “鈫” (shan) was created for samarium. One of its previous name “鎷” ( $m a)$ was "the phonic equivalent to its second syllable" and another one “鎩” (sha) was rejected because it has too many strokes. The earlier names for neodymium (“釹”, nï) included "鋖” (si or tuo) and “釢” (nai). The word “釢” looks similar the word “诵” (nai, neon). They determined to use “鋖” instead [34]. The Principles of Chemical Nomenclature has determined 89 element's names. Among them, masurium (atomic number 43) and illinium (atomic number 61) were proven to have been misidentified and then repealed. Only three new names “鉿” (ha, hafnium), “金”” (po, polonium), “錸” (lai, rhenium) have been created.

The Revised Principles of Chemical Nomenclature, published in 1945, only changed three elements' names. The changes include from “氭” to “氡” (dong, radon), from “鍕” to “釷” ( $g a$, gadolinium), and from “鈳” to “鈮” ( $n i$, niobium) [39]. Three new elements of atomic numbers 85 (alabamine), 87 (virginium) and 91 (protactinium) were added.

The former two elements were marked as unconfirmed findings [40]. Later, these two proposed new elements were both rejected. The element protactinium was named "鎂” (pu) for good.

\section{Japanese element names}

Japan's introduction to modern science by Dutch sources was two to three decades earlier than that of Late Qing China. Several known elements already had Japanese names as early as the 1830s. For example, the book Enzai Iho Meibutsukou (遠西醫方名物考) already named “酸素” (oxygen), “水素” (hydrogen), and “炭素” (carbon). Another book Kikai Kanran (気海観瀾) published later mentioned several more elements, including “清氣” (oxygen) and “窒 氣” (nitrogen) [41]. The element nitrogen as “窒素” (chisso, nitrogen) first appeared on Shokugaku Keigen (植学啓原) by Utagawa Yuan (宇田川榕菄) [42]. The book Seimi Kaisou (舍密開宗, Epitome of Chemistry), translated in 1837, has become one of the ground-breaking books on Japan's history of chemistry. Many of its names set the golden rules for Japan's chemical naming. Many names introduced by this book are still used in modern Japanese such as “酸素” (sanso, oxygen), “水素” (suiso, hydrogen), “窒素” (chisso, nitrogen), and “炭素” (tanso, carbon) [43].

In addition to traditional Japanese names, Seimi Kaisou introduced new names such as “硫黃” (iwo, sulfur), “燐” (lin, phosphorus), “砒” ( $h i$, arsenic), “黃金” (ougon, gold), “銀” (gin, silver), “銅” (dou, copper), “錫” (ssu, tin), “鉄” (tetsu, iron), “鉛” (namali, lead), “亞鉛” (aen, zinc), and “水 銀” (suigin, mercury). Some non-metal elements contained the word “素” (essence), for example, “酸素” (sanso, oxygen), “水素” (suiso, hydrogen), “窒素” (chisso, nitrogen), and “炭素” (tanso, carbon). Most metal elements were written in phonic-transcribed kanji or Manyogana (万葉仮名) such as “亞律密烏母” (arumiumu, aluminium), “加爾丘 母” (karuchomu, calcium), “麻倔涅堅母” (maguneshiya, magnesium), “加熘母” (kariumu, potassium), and “曹䡒 母” (soudjiumu, sodium). “蒼鉛” (souen, bismuth), “水鉛” (suien, molybdenum), and “白金” (hakkin, platinum) [44].

The author Utagawa Yuan coined these names from Dutch sources. For instance, four non-metallic elements, oxygen, hydrogen, nitrogen, and carbon were named based on zuurstof (acid substance), waterstof (water substance), stikstof (suffocation substance), and koolstof (coal substance) of Dutch that are formed by combining a root word and "-stof", the Dutch word for substance. The word “蒼鉛” was translated from asgrauwelood in which asgrauw means gray or pale white, and lood means metal lead. Another word “水鉛” (molybdenum) was translated from the word waterlood, or water plus lead. Similarly, “白金” (platinum) was 
translated from witgout where wit means white and gout means gold.

The naming of non-metal elements in Japanese has been in stagnation for many years until the publish of Rika Nikki (理化日記, Notes for the Physics and Chemistry Lectures) by Ichikawa Seizaburo (市川盛三郎). Except for sulfur which already has a deep-rooted traditional kanji name "硫 黄” (iwo), he added a word “素” (so, essence) to all other non-metal elements. The names created by him included " 弗素” (fuso, fluorine), “沃素” (youso, iodine), “砒素” (hiso, arsenic), “攝素” (seso, selenium), “䄪素” (siso, silicon), and “的素” (tekiso, tellurium) [45].

The Kagaku Yakugoshu of 1891 nearly single-handedly determined Japanese words for elements for the next half century. This was the first fruit contributed by the Chemical Society of Tokyo (東京化学会) in the field of chemical naming. The Chemical Society of Tokyo, established in 1878 , began to effort to standardize Japanese chemical names after the formation of its naming committee in 1881 [46].

In Kagaku Yakugoshu, most non-metal elements were written in kanji and ended with the word “素” (so, essence), such as “酸素” (sanso, oxygen), “水素” (suiso, hydrogen), “窒素” (chisso, nitrogen), “炭素” (tanso, carbon), “硼素” (houso, boron), “䂤素” (hiso, arsenic), “磷素” (rinso, phosphorus), and “的素” (siso, silicon). Halogens were written in both kanji and katakana, such as fluorine: “弗素” (fuso) / “7 ロル” (furoru), chlorine: “鹽素” (shoso) / “クロル” (kuroru), bromine: “臭素” (shuso) / “ブロム” (buromu), and iodine: “沃素” (yoso) / “ヨード” (yoodo). However, selenium (セレ ン, selen) and tellurium (テルル, teruru) were only written in katakana. In 1900, the Chemical Society of Tokyo published the first edition of Kagaku Goi (化学語彙, A Vocabulary of Chemical Terms). In this edition, existing non-metal element names were adopted except for the halogens where their katakana forms were abolished. Sulfur had a less conventional Japanese name. Unlike other traditional non-metal elements such as boron, arsenic, phosphorus, and silicon where the traditional single-word kanji name was added a “素” (so, essence), sulfur kept its traditional kanji name “ 硫黃” (iwo). Another noteworthy case was for boron. This word “硼素” (houso, essence of boron) was first coined by 化學訓蒙 (kagaku kunmou, An Introduction to Chemistry) by Ishiguro Tadanori (石黒忠息, 1845-1941) in the light of the Chinese term “嗍精” (pengjing, essence of boron) from the book Gewu Rumen (Introduction to Natural Philosophy) [47]. Two earlier Japanese books Seimi Kaisou (Epitome of Chemistry) [48] and Kagaku Nyuumon (化學入門, An Introduction to Chemistry) [49] used the kanji term “勃熘 母” (boryumu) and another book Kagaku Senyo (化学闡要, An Outline of Chemistry) coined the term “蓬素” (hoso) for boron [50].
The naming of metal elements in Japanese mainly followed the approach established by Seimi Kaisou (Epitome of Chemistry). In addition of the traditional names, the three meaningful names created by Utagawa Yuan were used by most chemical publications. All other metal names were phonetic transcribed. Before Meiji Restoration, kanji names were used. After the modernization movement, things began to change. The rise of kanji abolishment movement had many phonetic kanji names written in katakana instaead. Even though the Shogaku Kagakusho (小學化學書, Elementary School Chemistry) translated by Ichikawa Seizaburo did not create a large number of names, it established the trend of katakana naming [44]. Many phonetic kanji names such as “格魯密烏母” (kurumiumu, chromium), “䇢拔爾去母” (kobalutsumu, cobalt), and “加熘母” (karumu, potassium), " were later written as “クロム” (kuromu, chromium), “コバ ルト” (kobaruto, cobalt), and “功ウム” (kariwamu, potassium) in katakana. In the meantime, some Japanese chemists continued the use of transcribed kanji names. Except for traditional nouns and several meaningful nouns derived from Dutch, Japanese metal element names in Kagaku Yakugoshu were all written in phonetic katakana [51].

The 1900 publication Kagaku Goi (化学語彙, A Vocabulary of Chemical Terms) set the ground rules for naming Japanese elements for nearly 50 years. After the first edition, this book has been revised in 1906, 1918, 1928, and 1938 by the Chemical Society of Tokyo (東京化学会). From 1900 to 1938 , the Society only added new element names to the book. None of the 1900 names had been changed. All of the new names, metal and non-metal alike, inert gas included, were written in katakana. No new kanji names were added.

\section{Comparisons and exchanges}

The chemical elements were translated into Chinese in nineteenth century, nearly half of them were phonetic [52]. We can hardly see the urge for meaningful names of that period even though that really was the case. As a matter of fact, John Fryer did state that it would be better to create all new nouns meaningfully and the phonetic means were better reserved as the last resort [53]. In the creation of chemical names, the Educational Association (㿽智書會) and China Medical Missionary Association (博醫協會) fully agreed with him [3]. However, except for the ones named by Daniel Jerome MacGowan, Fryer and Xu created fewest meaningful names. He had named only seven elements meaningfully, “ 鋁” (lü, aluminium), “鉮” (shen, arsenic), “咘” ( $b u$, boron), “鉦” (gai, calcium), “鉀” (jia, potassium), “哆” ( $x i$, silicon), and “鈉” ( $n a$, sodium). Whether John Glasgow Kerr, Wilhelm Lobscheid, William A. P. Martin, Anatole Billequin or the Educational Association, they all tried to create names meaningfully or used the element's traditional names. 
Fryer and $\mathrm{Xu}$ were really out of options when they decided to go against the tide to adopt the phonetic approach. After all, it was an easier and often the only viable way. To create a name meaningfully, one has to fully understand the element's foreign language meanings. It was next to impossible to create a one-word descriptive name if the element was named after a nation, a place, or a person. It seems to be easier if one wants to name the element based on its own or its certain compound's color or selected property. However, this approach could be impractical to namers without adequate knowledge in chemistry. As a result, William A. P. Martin and Wilhelm Lobscheid both named very few elements meaningfully. Anatole Billequin could hardly do any better. In Huaxue Zhinan (A Guide to Chemistry), he had created 30 words for the elements. As late as 1891, he still had only named 62 elements in his Fahan Hebi Zidian (法 漢合壁字典, Chinese-French Bilingual Dictionary) which was two words fewer than that of the Huaxue Chujie (Basic Chemistry)—a book published about two decades ago. Among them, 46 words were newly coined. Four of them, “鎄” (erbium), “鈀” (palladium), “鋨” (yttrium), and “鐽” (tantalum) had to be phonetic. On the other hand, we really had to appreciate Anatole Billequin's unmatched contribution to create following 42 names meaningfully: “䂴” (alu-

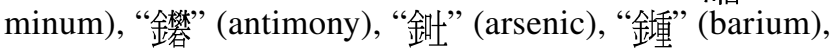
“鉗” (beryllium), “鈖” (bismuth), “殠” (bromine), “鐄霜”

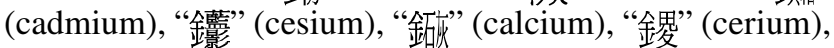
“錫” (chromium), “錆” (cobalt), “鐛” (determined a non-

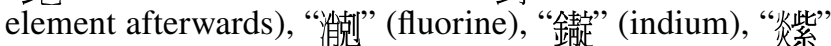
(iodine), “鉽” (iridium), “鍩” (lanthanum), “鉐” (lithium), “鐻” (magnesium), “䥊” (manganese), “錰” (molybdenum), “錊” (nickel), “鎙” (niobium), “鈜” (potassium), “ 鐚” (osmium), “硄” (phosphorous), “釷” (rhodium), “鋯 " (rubidium), “錟” (ruthenium), 坧” (selenium), “鋮”

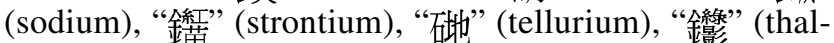
lium), “鐳” (thorium, the word “鐳” is now used by radium), “䤲” (titanium), “鑑” (tungsten), “鏔” (uranium), “錗 " (zinc), and “軉” (zirconium). The creation of meaningful names declined graduallyever since. Even though the Educational Association (㿽智書會) and China Medical Missionary Association (博醫協會) favored the meaningbased approach, they had used this method on only about one-fourth of the names created by them excluding the three names coined by Benjamin Hobson and several other traditional names This change can be illustrated by a closer look into the unaccepted 11 names created by Fryer and Xu.

From the 11 elements, Wilhelm Lobscheid created three meaningful nouns, Anatole Billequin had eight, and the Educational Association and China Medical Missionary Association had named only one which was “䤲” (strontium). Entering the twentieth century, these meaningful names all gave way to their phonetic equivalents. Both Hиахие Yuhui (A Chemical Vocabulary) and the list by the National
Medical and Pharmaceutical Association of China nearly adopted all the names used by Hиахие Jianyuan (Elementary Chemistry).

The changes of inert elements' names can be used to illustrate the methodological shift of nomenclature from meaningful to phonic names In the very beginning, the Educational Association and China Medical Missionary Association did use inert elements' literal meanings to create their Chinese names, for example, "閑" (xian, rested, argon), "曦" (xi, dawn, helium), "氞" (gas + first, argon), "氞" (gas + sun, helium), "璌" (gas + secret, krypton), and "氫" (gas + fresh, neon). The names created by the European Branch of the Chinese Chemical Society were all meaningful, such as "氞" (gas + sun, helium), "氫" (krypton), "璌" (neon) with only one exception "氛" (gong, argon) [54]. Since the publication of Huaxue Yuhui and Huaxue Mingci Caoan by the National Medical and Pharmaceutical Association of China, nearly all names were phonic. This change may be attributed to the popularization of the phonic names created by Fryer and Xu. The shift was also helped by the adoption of Japanese methodology.

The changes of Japanese names were driven by the reformation of Japanese writing system. During Japan's late Edo Period, people began to demand the reduction of kanji usage. Maejima Hisoka (前島 密, 1835-1919) submitted a proposal On the Reduction of Kanji Abolishment (漢字御廃 止之議) to Tokugawa Yoshinobu (徳川慶喜, 1837-1913), the de facto Japanese ruling warlord. He was known as the pioneer of kanji abolishment [55]. In 1886, Yano Ryuki (矢 野龍渓, 1851-1931), chairman of the News Post (郵便報 知新聞, Youben Hochi Shimbun) and later Japan's ambassador to China, published A New Proposal to the Japanese Writing System (日本文体文字新論) which proposed the reduction of kanji usage and the increase of katakana usage. In 1900, the government of Japan issued Detailed Rules for Elementary Schools (小學校令施行規則) that unified the rules of Japanese Latin transcription. This reformation promoted use of katakana in daily life and education [56]. In the same year, Inoue Enryo (井上円了, 1858-1919) published On the Absolute Necessity of Kanji Usage (漢字不可廃論) in defense of kanji. However, the increase of katakana usage overpowered his resistance.

Let us compare the use of words in Chinese and Japanese languages. Chinese used 11 traditional hanzi element names, “金” (jin, gold), “銅” (tong, copper), “銀” (yin, silver), “ 鐵” (tie, iron), “鉛” (qian, lead), “錫” (xi, tin), “录” (gong, mercury), “硼” (peng, boron), “磷” (lin, phosphorus), “硫” (liu, sulfur), and “碳” (tan, carbon). In addition to these 11 words or their equivalents, Japanese language used additional terms including “覀鉛” (aen, zinc), and “砒素” (hiso, arsenic). As to meaningful words, Chinese used “氧” (yang, oxygen), “氢” (qing, hydrogen), “氮” (dan, nitrogen), “氯” (liu, chlorine), “溴” (xiu, bromium), and “鉑” (bo, platinum). 
Japanese has “酸素” (sanso, oxygen), “水素” (suiso, hydrogen), “窒素” (chisso, nitrogen), “塩素” (enso, chlorine), “臭 素” (shuuso, bromium), “蒼鉛” (souen, bismuth), and “白 金” (hakkin, platinum) which is more than Chinese by one.

Chinese and Japanese used to have some quite similar halogen names. Japan's first use of 臭素, shuuso) for bromium was in the book Kagaku Senyo (An Outline of Chemistry) of 1875 by Toki Yorinori (土岐頼徳, 1843-1911). Chances are the use of this name could have been influenced by Huaxue Chujie of 1870. Even though Huaxue Chujie was translated and published into Japanese by Japan's Shurin Books, Co. and Aoyamado Books, Co. and its part on the elements was separately translated into Genso Ryakkai: Kagaku Shimon (原素略解:化学示蒙, A Rough Guide to the Elements: A Brief Introduction to Chemistry) by Yoshifumi Books, Co. Based on the time of its publication, it was probably unlikely for that Japanese book to have referenced the Chinese book. However, it was quite natural to have a very long delay for a Chinese book to be published in Japan. It was still possible for Yorinori to obtain a Chinese copy of that book for his own reference. Another case was the term “弗素” (fuso, fluorine). This term first appeared in the book Rika Nikki (理化日記, Notes for the Physics and Chemistry Lectures) by Ichikawa Seizaburo. This choice of word was probably influenced by Kagaku Nyuumon (An Introduction to Chemistry). The latter introduced the phonic names for fluorine, selenium, and tellurium. Ichikawa also consulted Huaxue Chujie and adopted the Chinese word “硼” (peng, boron) for the creation of its Japanese equivalent “硼素” (houso). We cannot rule out Huaxue Chujie's influence. In addition to Huaxue Chujie, metal names introduced by Huaxue Jianyuan, such as “鉀” (jia, potassium), “鎂” (mei, magnesium), “鈉” (na, sodium), “鋁” (lï, aluminium), had also been used in some Japanese chemical textbooks to a lesser extent [57].

More interestingly, words for potassium, sodium and tungsten in Chinese and Japanese were derived from Latin's kalium, natrium, and wolframium, rather than potassium, sodium, and tungsten of English [58]. However, in the revised 1918 version of Kagaku Goi, the Japanese name for tungsten began to change. Even though it was still called wolframium in the English-speaking world, the names “ウォ ルフラム” (wolframium) and “タングステン” (tungsten) were both listed in the appendix [59]. More and more chemical books used “タングステン” [60] which was very likely influenced by the industry because this term was widely used by the mineralogy [61], metallurgy [62], and electric industries [63].

Three names played the most important roles in Lavoisier's chemical nomenclature reformation. They also caused the greatest differences between Chinese chemical terms and their Japanese counterparts. They were: oxygène (acid forming), hydrogène (water forming), and azote (without life (in Greek), nitrogen).

An early form of the Chinese words for oxygen, hydrogen and nitrogen were “養氣” (yangqi, nourishment gas), “ 輕氣” (qingqi, light-weight gas), and “淡氣” (danqi, dilution gas). The Chinese understanding and interpretation of chemistry exactly followed Lavoisier's predictions in his «Traité élémentaire de chimie» (1789). In the preface of the book, he used the logical system of languages proposed by philosopher Abbéde Condillac (1715-1780) to emphasize the importance of chemical nomenclature reform. "People use language to think. Properly composed words make great logical deductions. The development of a science is driven by its practice of naming. Words are used to display the contents of ideas. Ideas are the simplest presentations of facts. In science, observed facts, descriptions of the ideas behind the facts, and the words to express the ideas, form an indivisible and mutually interacting troika." [64].

In the nineteenth century, oxygen, hydrogen, and nitrogen were translated into “養氣”, “輕氣”, and “淡氣”. Chinese scholars preferred to interpret the three elements' properties based on their literal meanings in a natural philosophical manner. As Chinese scholars began to be able to name on their own, they still believed that nourishment for oxygen was a better description [65]. Among the reasons, they thought Chinese scientists of that time, "still know too little chemistry" [66]. After about a century's learning and exploration and the increased studies on the history of science, one major problem still affects us. More and more of us were introduced to Lavoisier's chemical achievements. People still know too little about the importance and value of the word "oxygène" in Lavoisier's chemical revolution. They also fail to grasp the semantic differences between Lavoisier's original name and its Chinese interpretation.

The term "acid essence" for oxygen is a good starting point for discussion. This obsolete term and its unbearable variations still can be seen in many hospitals which really drive us crazy. Scientists of the eighteenth century mistook oxygen as the element shared by all acids and called it the "acid essence". It is difficult to see why Japanese people would keep on using this inappropriate name. After all, the element shared by all acids is, in fact, hydrogen. I always tell my students this joke, one day I was in a hospital when they put an oxygen mask on me. I saw "Essence of Acid" painted on a gas cylinder. It scared the hell out of me. It's a lousy joke but I tell it over and over anyway [67].

However, the same error is made by many other people as well because the name oxygen was created under the idea of "acid essence". Not just for Japanese speakers, English, French, German, all European and American language speakers all make the same mistake. Even Koreans and Vietnamese make this mistake, too. Their names for the oxygen element also were based on the idea of "acid essence". 
Even though the name for oxygen was based on an erroneous idea and the early use of it had been disliked by many under various grounds, such as nationalism, personal and school power struggles, nothing can be used to remove this name from science. The idea of oxygen as an element brought us into modern chemistry. The use of this term was first accepted by some, and then all [68].

\section{Discussion}

Time and time again, new names are generated. The new words created by an era are snippets from the sea of knowledge created or imported during it time period. New words, such as words for sodium, magnesium, potassium, and aluminium created in the nineteenth century, are never selfexplanatory. They must be introduced to the general public. Names based on their European spellings require more explanations and educational efforts to reach the mass than names based on traditional words. Sometime, new and unfamiliar words could be rejected. Take sodium as an example, the Chinese word “鈉” ( $n a$ ) was created from "natrium", a Latin noun. It was a time when very few educated Chinese could speak a second language. The concept for English and Latin as languages was foreign to them. Instead, introducing the word “鐻” ( $l u)$ to them, they could easily accept the idea that the element was a part of salt.

New nouns can hardly be disconnected from the traditional knowledge system. They must be created on top of people's knowledge. Upon seeing “碘” or “矽”, which has a stone radical (“石”), one knows they are non-metals. Seeing “溴”, which has a water radical (“沫”), one knows it is a liquid. Seeing “錳”, “鎂”, and “鉀”, which has a metal radical ("金”), it is immediately known that they are some metals. Unfortunately, many of the names may be reasonably explained by traditional knowledge but the implications are all scientifically misleading and wrong. Take oxygen, for example, the Chinese word for oxygen implies nourishment. People inhale oxygen to be nourished by it. This name seems to be quite faithful to the facts and the idea of nourishment seems to be correct. The name's implications are clearly shown by its literal meanings. As said by Abbéde Condillac's theory, facts, ideas, and words form an inseparable troika. Antoine-Laurent de Lavoisier looked at the same thing from a chemical perspective. He noticed that in experiment, whether phosphoric acid, sulfuric acid, or nitric acid, all acidic compounds contain an acid-forming element that he called oxygen. He created the theory of acidity based on oxygen. Then he expanded that theory to cover base and salt. When an acid and a base form a salt, the combined weight of the acid and the base must be equal to the weight of the salt plus other resulting matters (e.g., water). The idea of oxygen not just points to acid and base, it also leads to the conservation of mass in chemistry.

Even though the Chinese terms “氧” (yang, nourishment) and “酸素” (suansu, essence of acid) refer to the same element, oxygen, they encode two totally different sets of facts, observations and ideas. The word “氧” has neither qualitative nor quantitative meaning and restricts one's mental picture of the element to its own gaseous state. In addition, the word “氣” ( $q i$, gas, air, breath or life energy as in qigong) carried too much philosophical, paranormal and mystic meanings carried by the Chinese naturalist tradition. To make things even worse, these two terms can be contradictory. How can one breathe the "essence of acid" safely without burning his/her lungs? On the other hand, how does a gas that we have to breath tell us what is an acid and its relation to a base, and what do we get when an acid meets a base? Without these basic chemical concepts, one can hardly understand chemistry. The concept of "nourishment" cannot give you the idea. Despite the idea "essence of acid" is far from perfect, it opens the door to further chemical studies.

The creation of “氧氣” (yangqi, nourishment gas) cannot properly be contributed to traditional Chinese knowledge or the unsuccessful attempt to establish the Chinese-origin for European knowledge. After all, Benjamin Hobson, William A. P. Martin, John Glasgow Kerr, and John Fryer all preferred these names. Even if they had known the historical importance of oxygen in the development of science, they probably knew very little about the name itself. More likely than not, they could not tell the differences between the nourishment gas and the essence of acid. Furthermore, the word "oxygen" was also disapproved by some chemists.

We can never establish a coherent nomenclature for the elements, inorganic and organic compounds in Chinese and Japanese. Among the halogens, the phonic name “碤” (dian, iodine) has nothing to do with the element's meanings while “氯” (lü, green, chlorine) and “溴” (xiu, odor, bromine) both are meaningful names. In Japanese, “塩素” (enso, essence of salt, chlorine) and “臭素” (shuuso, essence of odor, bromine) are meaningful, while “弗素” (fuso, fluorine) and “沃 素” (youso, iodine) are phonic. Japanese non-metal names are similarly divided. Not all non-metal elements have a “素” ( $s o$, essence). Some are written in meaningful kanji while others are in phonic kanji. Some others are written in katakana. Each name has its own long story to tell. There is no way to establish an ad hoc rule for naming. The vicissitude of names very likely reflects the great changes in the importation and interpretation of knowledge through time.

Chemical terms must mean something chemical to us. You can name an element after its own color, taste or properties or its well-known compound's said properties. However, most Chinese and Japanese chemical names seem to lack that kind of chemical flavor. Many elements were 
named by non-chemists which could have been the reason. After all, Fryer, Xu, and Utagawa were not chemists. Ever since late nineteenth century, Japanese chemists began to name their chemical substances and the same thing happened to Chinese chemists in the early twentieth century. Nevertheless, we may notice the names created by chemists did not become more "chemical" because they knew more about chemistry whether in Japan or China. In contrast, fewer and fewer meaningful names were created to the point that they almost went extinct. An exception can be seen in China that the Science Noun Review Committee did create some meaningful organic terms. However, when the National Institute for Compilation and Translation entered the scene, they used phonic approach almost exclusively. In Japan, katakana became the most preferred approach since late nineteenth century. Names created by Japanese chemists did not become more chemically meaningful because of the methodology. The phonic approach, easier to implement, was selected by both countries.

Every student of chemistry knew it if a name was coined in a meaningful way, memorization can be easier. You may also get to know more about its philosophic and historic backgrounds to form a more complete mental image. However, Chinese and Japanese elements and organic compound names seldom present the noun's systematic knowledge framework. It was mostly caused by the creation of phonic Chinese new words, and the use of katakana in Japanese. Another difficulty was from the standardization of organic names of the western word. Under the standard scheme, an organic compound is named using a carbon number prefix and a root describing the type of the organic compound. However, it has become impossible for a Chinese speaker to stuff all these meanings into a single word. There are many meaningful chemical words in European languages. On the other hand, much fewer meaningful chemical words are in Chinese and Japanese. To create a word that carries an idea's systematic background knowledge, whoever names it must have the knowledge in the first place. However, this is usually too good to be true. We cannot ask them to have such a complete base of humanity and natural science knowledge. As a result, there is hardly any chance for a learner to form a whole mental picture of chemical science from the study of localized chemical terms.

Each era has its favorite way to describe things. The nineteenth century Chinese people preferred meaningful names. It is easy to see that names created by Anatole Billequin shall be most popular. However, the creation and public exposure of these meaningful names could hardly catch up with the progress of science. Failure to introduce a more complete picture of chemistry was a reason of their disuse.

Furthermore, these nouns did not have a good way to spread. Students of Beijing Tongwenguan were exposed to modern science, yet many of them still chose to study traditional knowledge to enter the government to work as a bureaucrat. In contrast, many scholars who had abandoned politics learned and spread phonic-based names in Jiangnan Arsenal.

\section{Conclusion}

Chinese and Japanese names of chemical elements were mostly originated from the Western World. Western chemical nomenclature, based on Antoine Lavoisier's theory and experiments, was seen as a scientific language. However, affected by the linguistic barrier and medium, many Chinese and Japanese names did not share the same meanings as their Western originals. The Chinese chemical names were created fundamentally different from Lavoisier's names.

The great influence posed by Chinese natural philosophy can be illustrated by the naming of oxygen, hydrogen, and nitrogen. The word "oxygen" infers acidity. If a compound contains oxygen, such a compound shall be acidic. The more oxygen it contains, the stronger the acidity. Furthermore, we may learn whether a compound is acid, basic, or a salt by reviewing its name given by Antoine Lavoisier. The word "hydrogen" infers to water. It was used to illustrate the element's ability to form water with oxygen. Front this point-of-view, we may notice that the current Chinese names for oxygen, hydrogen, and nitrogen failed to present these chemical properties. Many of them were named disregard for their original European meanings. They were named based on the Chinese philosophical theory of yin and yang. Listed below are the reasons that the Chinese used the yin and yang theory to name oxygen and nitrogen. First, Chinese people preferred to comprehend European ideas within the existing Chinese framework. For example, Chinese scholars used the traditional Five-Element theory (wu xing, 五行) to explain the European Four-Element theory during the late Ming Era. Second, some European scholars did use a binary theory to explain the co-existence of oxygen and nitrogen in the atmosphere. Despite oxygen was needed for breathing, the existence of oxygen in the air must be balanced by the introduction of nitrogen. These ideas provide an opportunity for the Chinese scholars to explain the relationship between oxygen and nitrogen using the yin and yang theory. Undeniably, the help from some European missionaries also promoted this approach. For instance, Benjamin Hobson, William A. P. Martin, and John Fryer all agreed to name oxygen “氧氣” (yangqi, nourishment gas) and nitrogen “淡 氣” (danqi, dilution gas). Finally, and very importantly, the name oxygen was questioned in Europe and that affected its adoption in China.

In addition to the yin and yang theory, the way Chinese people coin new characters also played a great role in it. 
Many Chinese element names were created with radicals affixed to the stem based on the element's physical properties. The radicals are used to show whether an element is a gas, metal, solid or liquid. Except for very few ones, such as chlorine and bromine, Chinese preferred to use phonic names. However, many chemical names were created meaningfully, such as iodine, helium, and neon. Chinese people used the phonic approach because it was easier. The word's creator did not need to investigate the word's origin. No need to check if it was from Latin, Greek, a god in the Greek myth, or a country's name. This saved much time for the authors. To Chinese students, they only needed to learn one English word. However, they were denied of an exposure to the Western Culture.

As to the Japanese chemical names, most newly discovered ones were phonic. Chinese and Japanese shared the same phonic approach. Some of the Japanese names were written in kanji, while others in katakana. The names for oxygen, hydrogen, and nitrogen constitute the most evident difference between Chinese and Japanese names. The three Japanese names were created based on their original European meanings. Another major difference between Chinese and Japanese names was that some Japanese names were influenced by Dutch.

Here we need to emphasize it again. Even though the phonic approach was easier to nineteenth century Chinese authors, their readers could find it more difficult to understand. It was not the case in Japan. Japanese people usually write down Western nouns in katakana. Even though the phonic approach was not the best choice, the massive efforts made by Fryer and Xu Shou helped these names to survive. Based on our studies, the nineteenth century phonic names of elements were mostly created by Fryer and Xu. These names not only showed up in their chemical books, they also showed up in their mining, metallurgy, and medical books. The quality and quantity of these translated books far exceed the ones translated by others at the same period of time. They provide Chinese readers a much more complete picture of science and technology. That was why names created by Fryer and Xu made it to today. Their names were not better. As a result, early twentieth century Chinese readers were used to these phonic names. This approach became the norm.

\section{References}

1. Xiong YZ (1994) Xixue dongjian yu wan Qing shehui [The dissemination of Western knowledge and late Qing society]. Shanghai People's Publishing House, Shanghai

2. Huang JF (2012) Yachang suiyue: Kaohsiung liusuanya gufeng youxian gongsi [Time of fertilizer factory: Kaohsiung ammonium sulfate company]. National Science and Technology Museum, Kaohsiung

3. Mateer CW (1898) The revised list of the chemical elements. Chin Rec Mission J 29:87-94

4. Fownes G (1863) A manual of elementary chemistry, theoretical and practical. Churchill, London

5. Xie HL (1905) Huaxue- zhongxue yong [Chemistry-for secondary school]. Zhongxi yishe, Shanghai

6. Chang H (2011) Zhongwen an an an zhi youlai [The development of chinese terms for ammonia, ammonium, and amines]. Chin J Hist Sci Technol 32:522-529

7. Yongli huaxue gongye gongsi (1946) Yongli huaxue gongye gongsi liusuanya chang chengli jingguo ji qi gaikuang [The establishment process and overview of Yongli chemical industry company's ammonium sulfate factory]. Tianjin

8. Ritter H (1870) Rika nichiki [Notes for the physics and chemistry lectures]. Itamiya zenbei, Osaka

9. Chuutaku G, Seisui T (1891) Kagaku yakugoshuu [Chemical vocabulary]. Shuuei sha, Tokyo

10. Jiten R (1939) Japanese dictionary of physics and chemistry. George Wahr, Michigan

11. Yang YH (1890) In: Wang T (ed) Kezhi shuyuan keyi [Themes of the Shanghai Polytechnic Institute]. Kezhi shuyuan, Shanghai

12. Fryer J (1881) Science in China. Nat 24:9-11

13. Hobson B (1855) Bowu xinbian [New treatise on natural philosophy and natural history]. Mohai Shuguan, Shanghai

14. Kerr JG (1893) Native and foreign medicine in China. In: paper presented at transactions of the forty-eight annual meeting of the Ohio State Medical Society. Cincinnati

15. Chang $H$ (2002) Yang qing dan de fanyi [The Chinese translations of oxygen, hydrogen and nitrogen: 1896-1944]. Stud Hist Nat Sci 21:123-134

16. Martin WAP (1868) Gewu rumen [Introduction to natural philosophy]. Tongwen College, Beijing

17. Martin WAP (1901) The lore of Cathay. Fleming H. Revell Company, New York

18. Wu YR (1983) Ershinian mudu zhi guai xianxiang [The strange thing of twenty years that we see]. Guiguan Press, Taibei

19. Fryer J, Xu S (1871) Huaxue jianyuan [Elementary chemistry]. Jiangnan Arsenal, Shanghai

20. Neal JB (1895) Treatises on chemistry. Chin Rec 26:187-190

21. Kerr JG, He LR (1870) Huaxue chujie [First steps in chemistry]. Boji Hospital, Canton

22. Wang YZ (1990) Guanyu huaxue jianyuan he huaxue chujie [Elementary chemistry: a source-book and first steps in chemistry]. Chin J Hist Sci Technol 11:84-88

23. MacGowan DJ, Hua HF (1872) Jinshi shibie [Discrimination of mineralogy]. Jiangnan Arsenal, Shanghai

24. Billequin A, Lian ZZ (1873) Huaxue zhinan [Guide to chemistry]. Tongwen College, Beijing

25. Lobscheid W (1866-1869) English and Chinese dictionary, with the Punti and Mandarin pronunciation. Daily Press Office, Hongkong

26. Graham T (1858) Elements of inorganic chemistry. Blanchard and Lea, Philadelphia

27. Wang SH (1971) Jidujiao jiaoyu hui ji qi chuban shiye [Christian educational associations and their publishing businesses]. Bull Inst Mod Hist Acad Sin 2:365-396

28. Dagenais F, Zhou PX, Han JC (2010) The John Fryer papers. Guanxi Normal University Press, Guilin

29. Mateer CW (1901) Chemical terms and nomenclature. American Presbyterian Mission Press, Shanghai

30. Kametaka T (1907) Putong xinti huaxue jiaokeshu [New stystem chemistry textbook]. Civilization Press, Shanghai

31. Fan DJ, Zhong GG (1908) Wuji huaxue jiangyi [Inorganic chemistry lectures]. Junyi Library Company, Shanghai 
32. Ikeda K (1907) Jinshi huaxue jiaokeshu [Modern chemistry textbook]. Scientific Instruments Company, Shanghai

33. Ministry of Education (1908) Huaxue yuhui [A chemical vocabulary]. The Commercial Press, Shanghai

34. National Institute for Compilation and Translation (1933) Huaxue mingming yuanze [Principles of chemical nomenclature]. Zhengzhong Press, Nanjing

35. General Committee on Scientific Terminology (1917) Huaxue mingci shenchazu diyici jilu [The first meeting minutes of subcommittee of chemical terms]. Chin Med J 3:24-45

36. Editorial Department (1920) Kexue mingci shenchahui diyici huaxue mingci shendingben [The first validated chemical terms of General Committee on Scientific Terminology]. Oriental Magazine 17:119-125

37. Yu FB (1917) Yixue mingci shenchahui dierci kaihui ji [Report on the second meeting of Joint Committee on Medical Terminology]. Chin Med J 3:15-17

38. General Committee on Scientific Terminology (1920) Yuansu mingci [The names of chemical elements]. Unknown Press

39. National Institute for Compilation and Translation (1945) Zengding huaxue mingming yuanze [The revised principles of chemical nomenclature]. Zhengzhong Press, Nanjing

40. Child PE (1998) In: Thurlow KJ (ed) Chemical nomenclature. Kluwer Academic, Dordrecht

41. Aochi R (1827) Kikai Kanran [Overall view of the atmosphere]. Izumiya Kichibei, Toto

42. Utagawa Y (1833) Shokugaku keigen [Introduction to the study of plants]. Seireikaku, Edo

43. Shimao E (1972) The reception of Lavoisier's chemistry in Japan. Isis 63:309-320

44. Sugawara K, Itakura K (1989) A historical study in japanese nomenclature of elements in the 1820s-1870s in Japan (1). J Hist Sci Jpn 28:193-202

45. Sugawara K, Itakura K (1990) A historical study in japanese nomenclature of elements in the 1820s-1870s in Japan(II). J Hist Sci Jpn 29:13-20

46. Nakazawa I, Shimizu T (1891) Kagaku yakugoshu [Collection of chemical translations]. Shueisha, Tokyo

47. Ishiguro T (1870) Kagaku kunmou [An introduction to chemistry]. Daito Gakko, Tokyo

48. Udagawa Y (1837) Seimi kaisou [Epitome of chemistry]. Seireikaku, Edo

49. Takehara H (1867-1870) Kagaku nyuumon [An introduction to chemistry]. Ikkando, Tokyo
50. Wells DA (1872) Kagaku senyo [An outline of chemistry]. Suzuki Kiuemon, Tokyo

51. Roscoe HE, Schorlemmer C (1877) Rakakufuru kagaku shinsho [New Roscoe's chemistry]. Eirando, Tokyo

52. Chang H (2015) Analysis of Chinese chemical language and terminology. Int J Lang Lit Linguist 1:246-249

53. Fryer J (1890) In: Records of the General Conference of the Protestant Missionaries of China Held at Shanghai, May 7-20, 1890. American Presbyterian Mission Press, Shanghai

54. The European Branch of the Chinese Chemical Society (1908) Zhongguo huaxuehui ouzhou zhihui wushennian baogao [1908 annual report of the European branch of the Chinese chemical society]. Unknown Press

55. Hayashi S, Minami F (1974) Meiji Taisho jidai no keigo [The polite formal language of the period of Meiji and Taisho]. Meiji Shoin, Tokyo

56. Inokuchi Y (1982) Meiji igo no Kanji seisaku [The police of Chinese character after Meiji era]. Japan Society for the Promotion of Science, Tokyo

57. Sanitary Bureau of Home Ministry (1879) Igaku nanaka mondo [Questions and answers on seven medical subspecialties]. The Tokyo Society of Medical Sciences, Tokyo

58. Takamatsu T, Sakurai J (1900) A chemical vocabulary. Taro tsuru ho, Tokyo

59. Wain H (1958) The story behind the word: some interesting origins of medical terms. Charles C. Thomas, Illinois

60. Tominaga H (1926) Muki kagaku [Inorganic chemistry]. Shokabo, Tokyo

61. Nihon Kogyo Shimbunsha (1917) Judo [baryta]. Nihon kogyo Shimbunsha, Tokyo

62. Kaziya H (1915) Saishin jitsuyou goukinn jutsu [Newest practical alloy]. Otsu Press, Tokyo

63. Doden H (1918) Tsuzoku denki kougaku kougi [Lecture for popular electricity]. Hiroshima Kann Press, Tokyo

64. Lavoisier AL (1790) Elements of chemistry. Creech, Edinburgh

65. Ouyang J (1890) In: Wang T (ed) Kezhi shuyuan keyi [Themes of the Shanghai Polytechnic Institute]. Kezhi shuyuan, Shanghai

66. Ren HJ (1915) Huaxue yuansu mingming shuo [Opinion for the naming of chemical elements]. Sci 1:157-166

67. Lu MS (2002) Yang jiao 'suansu' fei zhengque yongfa [Oxygen called 'acid element' is incorrect]. China Times

68. Bensaude-Vincent B, Abbri F (1995) Lavoisier in European context: negotiating a new language for chemistry. Science History Publications, Canton 